\title{
Long-term variability of dust events in Iceland (1949-2011)
}

\author{
P. Dagsson-Waldhauserova ${ }^{1,2}$, O. Arnalds ${ }^{1}$, and H. Olafsson ${ }^{2,3,4}$ \\ ${ }^{1}$ Agricultural University of Iceland, Hvanneyri, Borgarnes, Iceland \\ ${ }^{2}$ University of Iceland, Department of Physics, Reykjavik, Iceland \\ ${ }^{3}$ Icelandic Meteorological Office, Reykjavik, Iceland \\ ${ }^{4}$ Bergen School of Meteorology, Geophysical Institute, University of Bergen, Bergen, Norway \\ Correspondence to: P. Dagsson-Waldhauserova (pavla@1bhi.is)
}

Received: 26 May 2014 - Published in Atmos. Chem. Phys. Discuss.: 27 June 2014

Revised: 6 November 2014 - Accepted: 9 November 2014 - Published: 16 December 2014

\begin{abstract}
The long-term frequency of atmospheric dust observations was investigated for the southern part of Iceland and interpreted together with earlier results obtained from northeastern (NE) Iceland (Dagsson-Waldhauserova et al., 2013). In total, over 34 dust days per year on average occurred in Iceland based on conventionally used synoptic codes for dust observations. However, frequent volcanic eruptions, with the re-suspension of volcanic materials and dust haze, increased the number of dust events fourfold (135 dust days annually). The position of the Icelandic Low determined whether dust events occurred in the NE (16.4 dust days annually) or in the southern (S) part of Iceland (about 18 dust days annually). The decade with the most frequent dust days in S Iceland was the 1960s, but the 2000s in NE Iceland. A total of 32 severe dust storms (visibility $<500 \mathrm{~m}$ ) were observed in Iceland with the highest frequency of events during the 2000s in S Iceland. The Arctic dust events (NE Iceland) were typically warm, occurring during summer/autumn (May-September) and during mild southwesterly winds, while the subarctic dust events (S Iceland) were mainly cold, occurring during winter/spring (MarchMay) and during strong northeasterly winds. About half of the dust events in S Iceland occurred in winter or at subzero temperatures. A good correlation was found between particulate matter $\left(\mathrm{PM}_{10}\right)$ concentrations and visibility during dust observations at the stations Vík and Stórhöfði. This study shows that Iceland is among the dustiest areas of the world and that dust is emitted year-round.
\end{abstract}

\section{Introduction}

The frequency of dust episodes is monitored around many of the major desert areas of the world. Detailed and longterm studies on wind erosion variability can potentially explain the climatological and environmental changes in the past. Periodical dust occurrences can affect ecosystem fertility and spatial and temporal distribution of animal and vegetation species similarly to climate variations (Fields et al., 2010). Oceanic ecosystems receive high amounts of nutrient rich dust spread over large areas where deserts occur near the sea (Arnalds et al., 2014). The long-term dust variability studies based on meteorological observations present up to 90 year old records from North America, Africa, Asia and Australia (N'TchayiMbourou et al., 1997; Qian et al., 2002; Natsagdorj et al., 2003; Ekström et al., 2004; Jamalizadeh et al., 2008; Steenburgh et al., 2012). Engelstaedter et al. (2003) reported high dust activity at many weather stations located in high-latitude regions. Cold climate regions are represented by long-term dust frequency in Northeast (NE) Iceland (Dagsson-Waldhauserova et al., 2013). Dust emission intensity and deposition rates in active glacial environments have been found to be very high, in some cases far exceeding those in lower latitudes (Bullard, 2013). Ganopolski et al. (2009) calculated glaciogenic dust deposition $>50 \mathrm{~g} \mathrm{~m}^{-2} \mathrm{yr}^{-1}$ at the last glacial maximum, with the highest rates over northwestern Europe. Recently, the highest deposition rates of glaciogenic dust $\left(>500 \mathrm{~g} \mathrm{~m}^{-2} \mathrm{yr}^{-1}\right.$ ) are reported from Iceland (Arnalds, 2010, see also Bullard, 2013). 
Dust events in Arctic and subarctic regions have been observed in Alaska (Nickling, 1978; Crusius et al., 2011), Greenland (Bullard, 2013), Svalbard (Dornbrack et al., 2010) and Iceland (Arnalds, 2010; Prospero et al., 2012; Thorarinsdottir and Arnalds, 2012). Arctic coastal zones are considered the windiest regions on Earth (Eldridge, 1980). Strong winds in Iceland cause some of the most extreme wind erosion events recorded on Earth (Arnalds et al., 2013).

The highest dust emissions in Arctic regions occur in summer and early autumn (Nickling, 1978; Bullard, 2013; Dagsson-Waldhauserova et al., 2013). Dust concentrations in subarctic regions peak in spring (April-June, Prospero et al., 2012). In contrast, cold and winter periods have higher glaciogenic dust deposition than warm periods in the past (Ganopolski et al., 2009). Dust events are frequent during dry years (Steenburgh et al., 2012; Dagsson-Waldhauserova et al., 2013), but suspended dust is also observed in high precipitation and low wind conditions (Dagsson-Waldhauserova et al., 2014).

Iceland is an important source of volcanic sediments that are subjected to intense aeolian activity (Arnalds, 2010; Prospero et al., 2012; Thorarinsdottir and Arnalds, 2012; Arnalds et al., 2013) and is likely the largest glaciogenic dust source area in the Arctic-subarctic region. Total emissions of dust from Icelandic dust sources are of the range 30 to 40 million tons annually, with 5-14 million tons deposited annually over the Atlantic and Arctic oceans (Arnalds et al., 2014). Seven major dust plume sources have been identified (Arnalds, 2010). These sources are all in the vicinity of glaciers. The most active glacial flood plain, Dyngjusandur, covers an area of about $270 \mathrm{~km}^{2}$ with up to $10 \mathrm{~m}$ thick sediments and is the main source for dust events in NE Iceland and towards the Arctic (Dagsson-Waldhauserova et al., 2013). The major dust sources in South Iceland are Skeiðarársandur, Mýrdalssandur, Mælifellssandur, and Landeyjasandur, which result in dust transport towards Europe during northerly winds, but alternatively towards Reykjavík and North America during easterly winds. The Hagavatn plume area is the source for frequent dust events passing Reykjavík and the ocean southwest of Iceland towards North America. Glaciogenic dust from the Mælifellssandur area contains fine sharp-tipped shards with bubbles and $80 \%$ of the particulate matter is volcanic glass rich in heavy metals (Dagsson-Waldhauserova et al., 2014). Such physical properties of the particles allow rapid suspension of moist particles within only a few hours after rain. In situ measurements from other dust plume areas are not available.

Dust suspension is related to reduced visibility. Wang et al. (2008) found a good correlation between $\mathrm{PM}_{10}$ concentrations and visibility during dust observation. The visibilitydust relationship can be used to estimate dust concentration where no aerosol mass concentration measurements are conducted (Dagsson-Waldhauserova et al., 2013). The relationship between dust concentration and visibility has, however, not been investigated previously in Iceland.
The main objectives of this study were to explore the longterm (63 years) frequency of dust events in Iceland. Emphasis was given to determining the climatology and character of Arctic and subarctic dust events. In addition, the relationship between available dust concentrations and visibility during dust observation was investigated and the frequency of dust events placed in an international perspective.

\section{Methods}

\subsection{Meteorological data and PM measurements}

A network of 30 weather stations (15 in S Iceland, 8 in NE Iceland, and 7 in northwest (NW) Iceland) operated by the Icelandic Meteorological Office (IMO) was chosen for the study (Fig. 1). Note the closer distance of the weather stations to the dust sources (red areas) in S Iceland than in NE Iceland. Table 1 shows the duration of station operation: the majority of stations have been in operation since 1949. The data consist of conventional meteorological parameters such as wind velocity, wind direction, temperature and visibility, accompanied by visual observations of present weather. Notice that visibility was not measured but rather estimated by the observer, e.g. on the basis of the visibility of, and known distance to, several landmarks. Present weather refers to atmospheric phenomena occurring at the time of observation, or weather preceding the time of observation (IMO, 1981). The synoptic codes (ww) for present weather that refer to dust observation are 07-09, and 30-35 (WMO, 2009). In addition, codes 04-06 are considered, but only if the codes for primary or secondary past weather (ww1, ww2) are 03 for "blowing soil, dust, sand and dust storm" (IMO, 1981; Dagsson-Waldhauserova et al., 2013). The weather reports were made 3-8 times a day.

Meteorological observations (synoptic codes for dust including 04-06 and visibility) were evaluated with available particulate matter (PM) mass concentrations data provided by the Environmental Agency of Iceland (EAI). The PM 10 data were obtained from the permanent station in Reykjavík (Grensasvegur, since 1996) and temporary stations in Vík and Kirkjubæjarklaustur (2010-2011). The Reykjavík station is equipped with a Thermo EMS Andersen FH 62 I-R instrument; the Kirkjubæjarklaustur station with the Grimm EDM 365; and the Vík station with a Thermo 5014. The distance between the meteorological and EAI stations in Reykjavík and Kirkjubæjarklaustur is about $1 \mathrm{~km}$, and several kilometres in Vík. A data set of dust concentrations (1997-2002, 2010) from the high-volume filter aerosol sampler in Vestmannaeyjar (the Westmann Islands) was used for evaluation of the dust codes and visibility at the Stórhöfði station (Prospero et al., 2012). Daily dust concentrations were correlated with the minimum visibility reported from dust observations during the preceding $24 \mathrm{~h}$. 


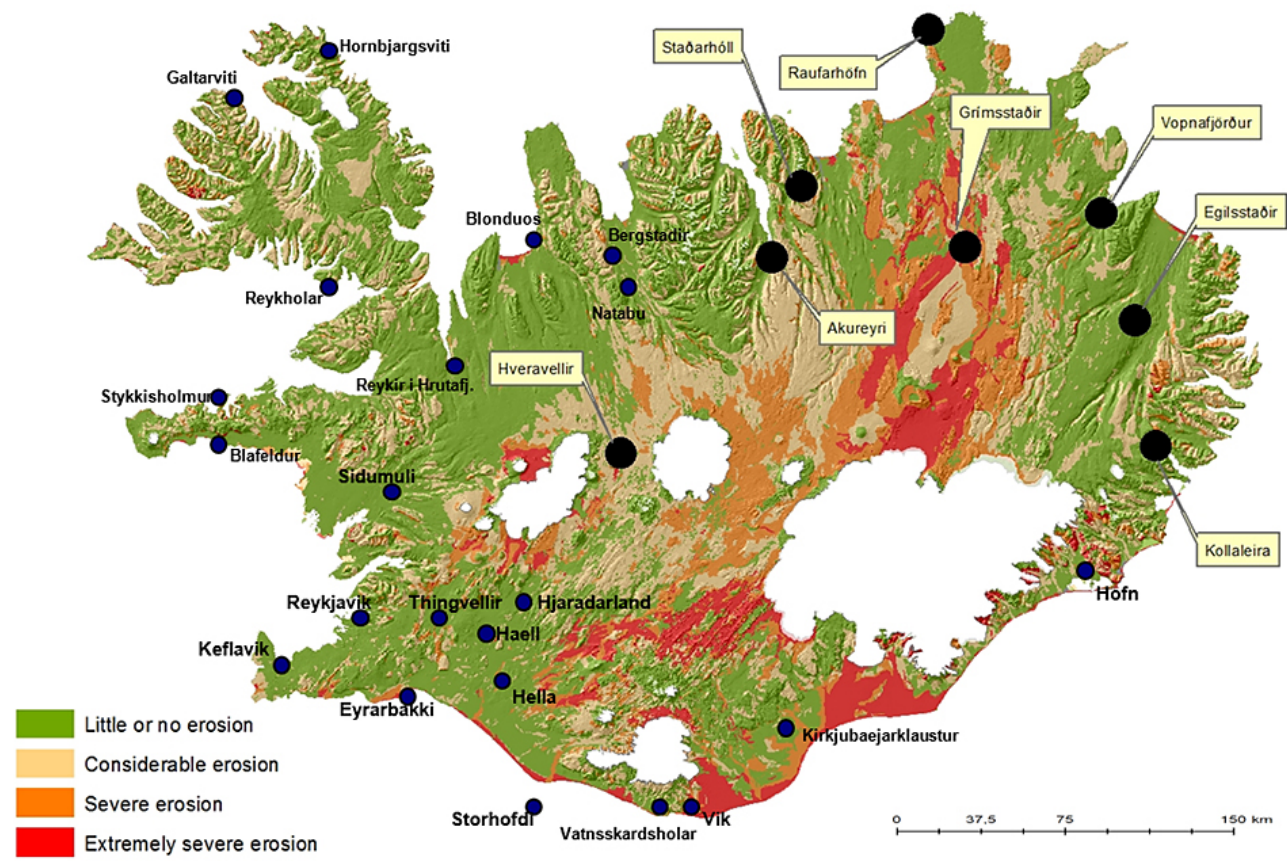

Figure 1. A map showing the locations of weather stations in northeastern and central Iceland (large black circles) and stations in the northwestern and southern part of Iceland (small circles). The red areas depict the major dust sources in Iceland. The base map is drawn from the Agricultural University of Iceland Erosion Database (Soil Erosion in Iceland).

Most of the conventional dust studies do not include the synoptic codes (04-06) for "visibility reduced by volcanic ashes", "dust haze" or "widespread dust in suspension in the air" into the criteria for dust observation (DagssonWaldhauserova et al., 2013). Comparing these codes with available dust concentration measurements showed that a $\mathrm{PM}_{10}$ concentration of $>41 \mu \mathrm{g} \mathrm{m}^{-3}$ (about twice the mean concentration) was exceeded in about $80 \%$ of the $04-06$ code cases. We did not include these codes in this long-term dust day study, except where the primary or secondary past weather (ww1 or ww2) was coded 03 . We included the codes 04-06 in case of the $\mathrm{PM}_{10}$ concentration and visibility analysis (see Sect. 2.2).

\subsection{Analysis}

The initial data set was built from the occurrence of "dust observation" made at one or more weather stations. Longterm dust activity was expressed in dust days. A "dust day" was defined as a day when at least one station recorded at least one dust observation. About $29 \%$ of the observations did not include information on the present weather and they were excluded from the data set. A dust event (DE) refers to the dust observation.

Dust concentration measurements can be compared to the weather observations at few stations in S Iceland and for a short time period. For the stations where $\mathrm{PM}_{10}$ measurements were available, we applied a power regression to determine the relationship between dust concentrations and visibility during dust codes, including 04-06 (methods detailed in Wang et al., 2008). Visibility during dust observation was used to classify the severity of dust events in the past (Dagsson-Waldhauserova et al., 2013).

\section{Results}

\subsection{Frequency, spatial, and temporal variability in dust production}

A mean of 34.4 dust days per year was observed in Iceland during the period 1949-2011. An annual mean of 16.4 dust days (total of 1033 days) was recorded in NE Iceland (Dagsson-Waldhauserova et al., 2013) and about 17.9 dust days (total of 1153 days) in southern parts of Iceland in 1949-2011. Figure 2 shows that the most dust-active decade in Iceland was the 1960s, while the lowest number of dust days occurred in the 1980s. For S Iceland, the highest frequency of dust events was in the 1950s-1960s, whereas the 2000s had the most frequent dust days in the NE Iceland. The Grímsstaðir station (NE) is the dustiest weather observation location in Iceland with $>12$ dust days annually. The following dusty stations with $>3$ dust days annually are represented in Table 2: Höfn (S), Vatnsskarðshólar (S), Egilsstaðir (NE), and Hella (S). The stations with highest dust frequency in the S Iceland are displayed in Fig. 2 (NE stations published in Dagsson-Waldhauserova et al., 2013a). The stations Höfn and Vatnsskarðshólar reported the highest number of 
Table 1. Weather stations in Iceland reporting synoptic observations. Observation period, number of dust observations, dust days and dust days per year are included. Stations are listed in descending order of number of dust days.

\begin{tabular}{|c|c|c|c|c|}
\hline Station & Observation period & Dust days & Dust observations & Dust days per year \\
\hline Grímsstaðir & 1949-2011 & 791 & 1685 & 12.6 \\
\hline Höfn & 1949-2011 & 243 & 575 & 3.9 \\
\hline Vatnsskarðshólar & 1949-2011 & 234 & 408 & 3.7 \\
\hline Egilsstaðir & 1949-1998 & 192 & 386 & 3.8 \\
\hline Hella & 1958-2005 & 179 & 368 & 3.7 \\
\hline Kirkjubæjarklaustur & 1931-2011 & 158 & 274 & 2 \\
\hline Stórhöfði & 1949-2011 & 118 & 204 & 1.9 \\
\hline Hæll & 1949-2011 & 94 & 132 & 1.5 \\
\hline Hveravellir & 1965-2004 & 91 & 124 & 2.3 \\
\hline Eyrarbakki & 1957-2011 & 80 & 120 & 1.5 \\
\hline Vík & 1961-2011 & 76 & 96 & 1.5 \\
\hline Keflavík & 1952-2011 & 68 & 96 & 1.1 \\
\hline Vopnafjörður & 1961-2011 & 64 & 83 & 1.3 \\
\hline Pingvellir & 1949-1984 & 56 & 81 & 1.6 \\
\hline Reykjavík & 1949-2011 & 41 & 70 & 0.7 \\
\hline Raufarhöfn & 1949-2011 & 41 & 61 & 0.7 \\
\hline Hjarðarland & 1990-2011 & 38 & 56 & 1.7 \\
\hline Síðumúli & 1949-2011 & 30 & 37 & 0.5 \\
\hline Akureyri & 1949-2011 & 26 & 26 & 0.4 \\
\hline Galtarvíti & 1953-1994 & 15 & 16 & 0.4 \\
\hline Staðarhóll & 1961-2011 & 12 & 15 & 0.2 \\
\hline Stykkishólmur & 1949-2011 & 9 & 13 & 0.1 \\
\hline Reykhólar & 1961-2004 & 8 & 9 & 0.2 \\
\hline Kollaleira & 1976-2007 & 5 & 7 & 0.2 \\
\hline Blönduós & 1949-2003 & 5 & 6 & 0.1 \\
\hline Natabú & 1949-2004 & 3 & 4 & 0.1 \\
\hline Bláfeldur & 1998-2011 & 2 & 2 & 0.1 \\
\hline Bergstaðir & 1978-2011 & 2 & 2 & 0.1 \\
\hline Hornbjargsviti & 1949-2004 & 1 & 1 & 0.02 \\
\hline Reykir í Hrútafirði & 1997-2011 & 1 & 1 & 0.1 \\
\hline
\end{tabular}

Table 2. Dust event classification based on visibility criteria. Frequency of dust events, mean wind velocity, mean temperature, and annual number of dust days of each dust class are included. S is the southern part and NE the northeastern part of Iceland.

\begin{tabular}{|c|c|c|c|c|c|c|c|c|c|}
\hline \multirow[t]{2}{*}{ Dust event class } & \multirow[t]{2}{*}{ Visibility $(\mathrm{km})$} & \multicolumn{2}{|c|}{ Frequency $(\%)$} & \multicolumn{2}{|c|}{ Wind velocity $\left(\mathrm{m} \mathrm{s}^{-1}\right)$} & \multicolumn{2}{|c|}{ Temperature $\left({ }^{\circ} \mathrm{C}\right)$} & \multicolumn{2}{|c|}{ Number of dust days per year } \\
\hline & & $S$ & $\mathrm{NE}$ & $S$ & $\mathrm{NE}$ & $S$ & NE & S & $\mathrm{NE}$ \\
\hline Severe dust storm & $\leq 0.5$ & 1.2 & $<1$ & 15.7 & 16.2 & -1.7 & 8.4 & 0.3 & 0.2 \\
\hline Moderate dust storm & $0.5-1.0$ & 3.5 & 2 & 13.6 & 14.9 & 4.1 & 9.4 & 1.1 & 0.5 \\
\hline Severe haze & $1.0-5.0$ & 14 & 10 & 15.0 & 13.0 & 1.1 & 10.6 & 3.0 & 2 \\
\hline Moderate haze & $5.0-10.0$ & 17 & 13 & 14.7 & 11.3 & 1.7 & 10.9 & 4.1 & 3 \\
\hline Suspended dust & $10.0-30.0$ & 42 & 46 & 13.5 & 9.9 & 3.0 & 10.6 & 10 & 10 \\
\hline Moderate susp. dust & $30.0-70.0$ & 16 & 27 & 11.7 & 10.2 & 3.7 & 10.0 & 6 & 7 \\
\hline
\end{tabular}

dust days in the 1950s-1960s; the station Hella observed the highest dust period in the 1960s-1970s; and a new station in Hjarðarland (established in 1990) was the most active in the 2000s. Dust events were less severe in the 2000s than in the 1950s-1990s, as reflected by increased visibility during dust observations. Mean visibility during dust observations in S Iceland was $23.3 \mathrm{~km}$, indicating more severe dust events in $\mathrm{S}$ than in NE Iceland (mean DE visibility $26.7 \mathrm{~km}$ ) or that weather stations in $\mathrm{S}$ Iceland are closer to major dust sources. Including codes 04-06 into the criteria for dust observation, the annual mean dust day frequency was 135 dust days with 101 dust days observed in S Iceland and 34 dust days in NE Iceland. 

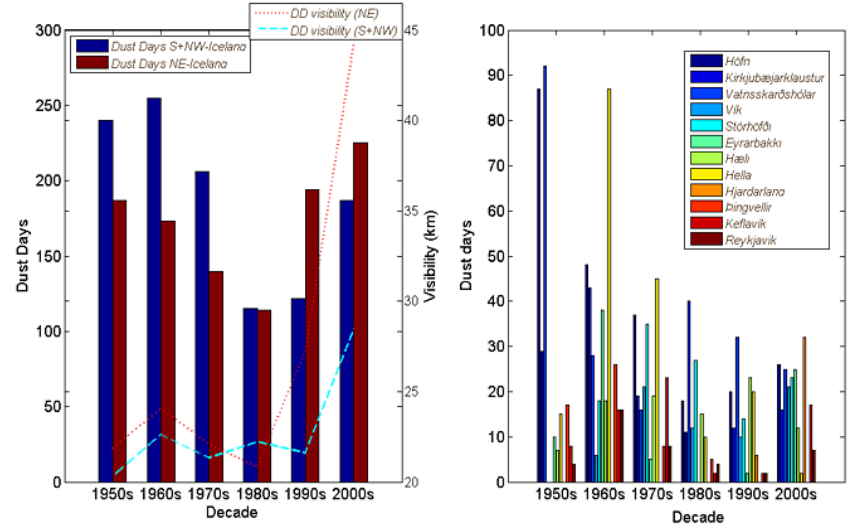

Figure 2. Left panel: total number of dust days, all stations combined (blue bars for southern and northwestern Iceland, brown bars for northeastern Iceland). Lines represent mean visibility (blue for $\mathrm{S}$, brown for NE Iceland). Right panel: individual stations in south Iceland sorted by decade.

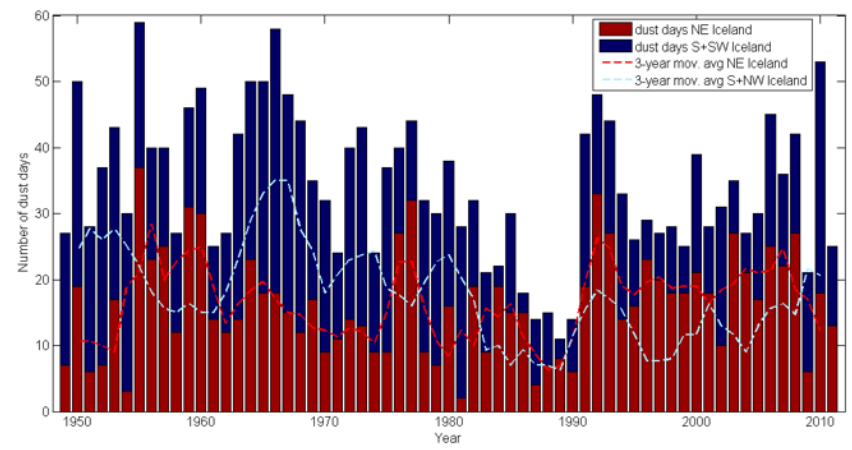

Figure 3. Number of dust days (blue bars for the southern and northwestern part of Iceland, brown bars for northeast Iceland) and 3 year moving averages of dust day frequency (lines: red for NE, light blue for S Iceland).

\section{Annual and seasonal dust day variability}

The annual number of dust days in 1949-2011 is depicted in Fig. 3. The dustiest years were 1955, 1966 and 2010, when over 55 dust days occurred annually. The least dusty period was 1987-1990 with 11-15 dust days annually. Dust events occurred more frequently in S Iceland than in NE Iceland in 1949-1954, 1962-1975, 1978-1981, and 2009-2011. The NE dust events were observed more often in 1955-1961, 1976-1977, 1982-1986, and 1992-2008 (except 1994 and 2003). There is a tendency for either the south or the north to be more active at a given time. Dust events observed on the south coast of Iceland and NE Iceland usually do not occur on the same dust day. The years with relatively severe dust events (and annual visibility during dust observations $<15 \mathrm{~km}$ ) were 1949, 1966, 1975, 1996, and 1998.

The seasonal distribution of dust days in $\mathrm{S}$ Iceland showed that about $47 \%$ of dust events occurred in winter

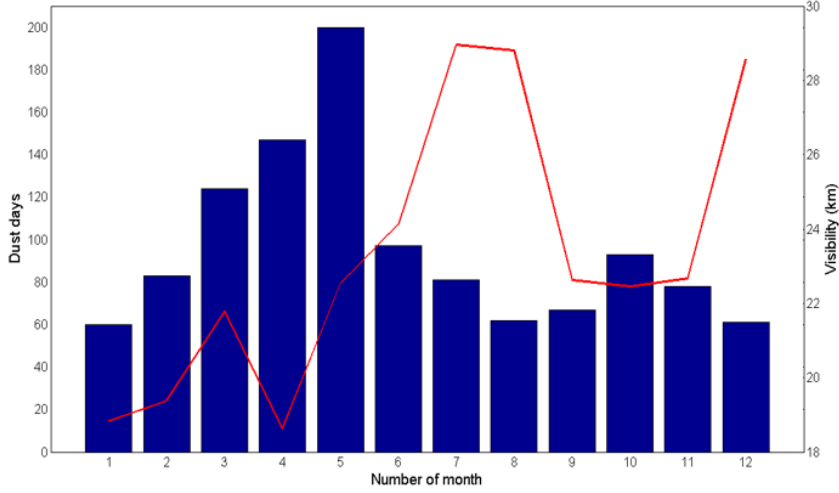

Figure 4. Number of dust days per month (bars) and monthly means of dust visibility (line) in the southern part of Iceland, 1949-2011.

(November-March) or during sub-zero temperatures. Dust days, as shown in Fig. 4, were most often in May (18\% of dust days), April (13\%) and March (11\%). The lowest occurrence of dust days $(<6 \%)$ was in January, December, August and September. In contrast, dust events in NE Iceland occurred mainly in summer and early autumn (MaySeptember, Dagsson-Waldhauserova et al., 2013).

\subsection{Climatology of dust events}

\subsubsection{Long-term trends in meteorological parameters of dust events}

The mean DE temperature in S Iceland was $3{ }^{\circ} \mathrm{C}$ with a minimum $1.4^{\circ} \mathrm{C}$ in the $1960 \mathrm{~s}$ and a maximum $5^{\circ} \mathrm{C}$ in the $2000 \mathrm{~s}$ (Fig. 5a). There was a great variability in $\mathrm{DE}$ temperatures, especially during the most active dust decade, the 1960s. The DE were the coldest in NE Iceland during the 1960s, but the warmest DE period was the 1950s (Dagsson-Waldhauserova et al., 2013). The mean DE temperature in the NE was significantly higher than in S Iceland, about $10.5^{\circ} \mathrm{C}$. The temperature differences are only related to dust observation because the mean annual temperature in S Iceland $\left(4.7^{\circ} \mathrm{C}\right)$ is higher than the mean annual temperature at the $\mathrm{N}$ Iceland stations $\left(1.5^{\circ} \mathrm{C}\right)$.

Dust observations in $\mathrm{S}$ Iceland reported high mean $\mathrm{DE}$ wind velocity of $13.6 \mathrm{~m} \mathrm{~s}^{-1}$, where the maximum mean of $15.6 \mathrm{~m} \mathrm{~s}^{-1}$ was during the $1980 \mathrm{~s}$ and the minimum of $11.9 \mathrm{~m} \mathrm{~s}^{-1}$ during the 2000s (Fig. 5b). Extreme DE winds exceeding $30 \mathrm{~m} \mathrm{~s}^{-1}$ occurred mainly in the $1960 \mathrm{~s}$ and the 1970s. The mean DE wind velocity in NE Iceland was $10.3 \mathrm{~m} \mathrm{~s}^{-1}$ with the maximum of $11.9 \mathrm{~m} \mathrm{~s}^{-1}$ during the 2000s and the minimum of $8.6 \mathrm{~m} \mathrm{~s}^{-1}$ in the 1980s (DagssonWaldhauserova et al., 2013).

The most common wind direction during dust events in $\mathrm{S}$ Iceland was $\mathrm{N}-\mathrm{NE}$, mainly reported from the stations Höfn, Hella, Vatnsskarðshólar, Kirkjubæjarklaustur, Stórhöfði, Eyrarbakki, Vík, Pingvellir, Hjarðarland, Keflavík, and Reykjavík (Fig. 6). Dust events were of- 

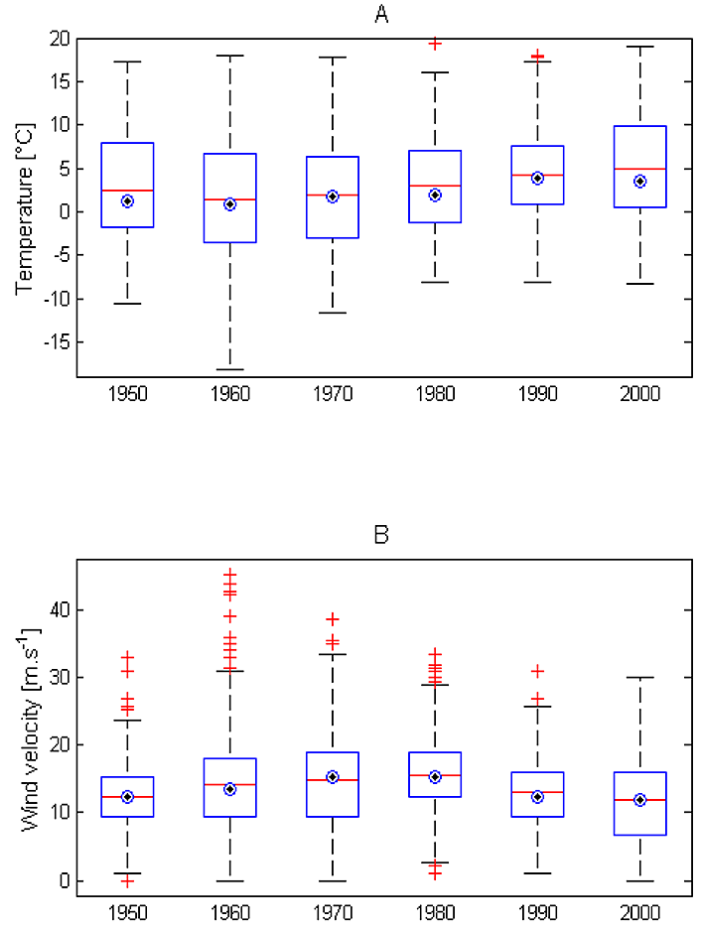

Figure 5. Temperature (a) and wind velocity (b) for dust events in the southern part of Iceland, 1949-2011. The boxes demarcate the range in which half the data can be found. The red lines represent the mean and the circles the median. Red crosses are extreme data points, outliers, which exceed the 25 or $75 \%$ quantile lines (quantile line extends maximally to 1.5 height of the central box).

ten observed from the wind direction E-NE (Hæll, Vatnsskarðshólar), E-ESE (Stórhöfði, Vatnsskarðshólar, Pingvellir, Reykjavík, Keflavík), NW-NNW (Höfn), and WWNW (Vatnsskarðshólar). The DE wind directions in NE Iceland were predominantly SW-S and SSE-SE (DagssonWaldhauserova et al., 2013).

\subsubsection{Seasonal patterns in meteorological parameters of dust events}

Seasonal variability in temperature and wind velocity during dust events in S Iceland is depicted in Fig. 7. The DE mean temperatures in the October-May period are several degrees lower than the long-term monthly temperatures (higher in June-August period). Generally, the DE temperature in S Iceland was about $1.7^{\circ} \mathrm{C}$ lower than the long-term mean. Contrarily, the DE temperatures in NE Iceland were about $3{ }^{\circ} \mathrm{C}$ higher than the monthly long-term temperatures (Dagsson-Waldhauserova et al., 2013).

The DE wind velocities were significantly higher (5$11 \mathrm{~m} \mathrm{~s}^{-1}$ ) than the long-term monthly wind velocities (Fig. 7b). The highest DE winds in S Iceland were from December to April, while the lowest DE winds occurred in summer (June-September). This corresponds to the long-

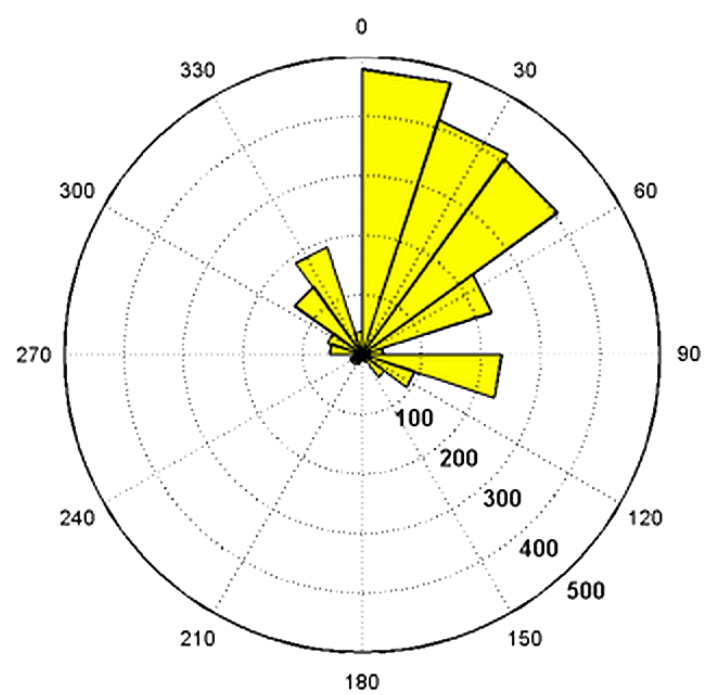

Figure 6. Wind directions during dust events in S Iceland in 19492011. Weather stations that observed mainly wind directions: 0$18^{\circ}$ - Höfn, Eyrarbakki, Kirkjubæjarklaustur, Stórhöfði, Pingvellir; 18-36º - Höfn, Vatnsskarðshólar, Hjarðarland, Reykjavík, Keflavík; 36-54 - Hella, Vatnsskarðshólar, Vík; 54-72 - Hæll, Vatnsskarðshólar; 90-108 - Stórhöfði, Vatnsskarðshólar; 270$306^{\circ}$ - Vatnsskarðshólar; and 306-342 ${ }^{\circ}$ - Höfn. Dashed circles depict the number of dust observations reporting relevant wind directions.

term monthly wind velocity trends. The mean DE wind velocity was $7.7 \mathrm{~m} \mathrm{~s}^{-1}$ higher than the long-term mean wind velocity. The difference was most pronounced during the winter months. The predominant winds during months of frequent dust events were NE and NNE winds in March and April (Fig. 8). The DE winds in May were also $\mathrm{N}$ and NE winds, but high proportion of $\mathrm{E}$ and ESE winds occurred during dust events. In NE Iceland, the DE winds were about 4-7 $\mathrm{m} \mathrm{s}^{-1}$ higher than long-term means with maxima in May and September-October (Dagsson-Waldhauserova et al., 2013). Generally, the DE winds were about $3 \mathrm{~m} \mathrm{~s}^{-1}$ lower in NE than S Iceland.

\subsubsection{Dust event classification and meteorology}

Reported dust events were of different severity. Where no atmospheric dust measurements are available, visibility during dust observation is used to estimate the dust event severity. Table 2 describes the dust event classes based on the visibility ranges. The most frequent were dust observations of "suspended" and "moderate suspended dust" (NE 73\%; S 59\%) with visibility 10-70 km, "severe" and "moderate haze" (NE $24 \%$; S $32 \%$ ) with visibility 1-10 km, and "severe" and "moderate dust storm" (NE 3\%; S 5\%) with visibility $<1 \mathrm{~km}$. There were 32 "severe dust storms" (visibility $<500 \mathrm{~m}$ ) observed in Iceland (14 in NE mostly in the 1950s, 18 in S mostly in the 2000s). 

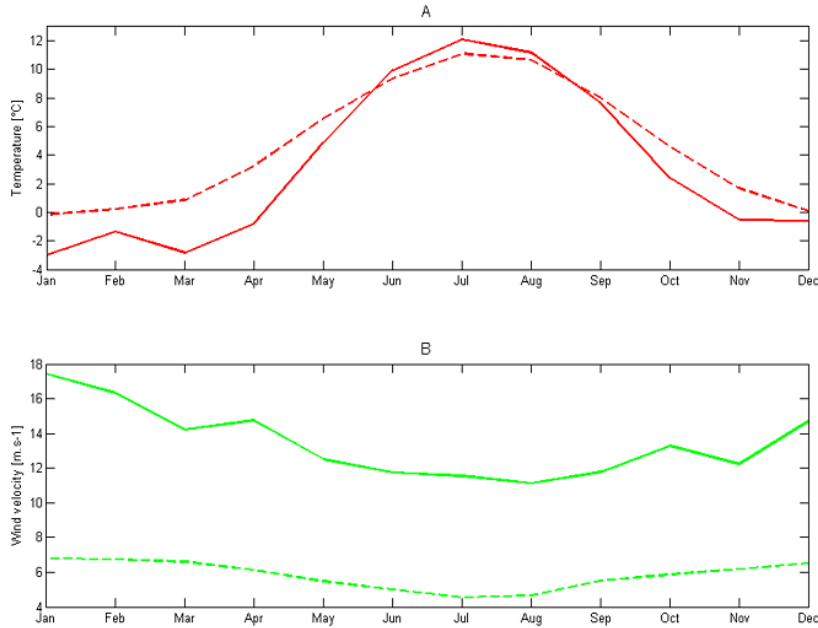

Figure 7. Monthly mean values (solid lines) and total mean values (dashed lines) of temperature (a) and wind velocity (b) during dust events in S Iceland, 1949-2011.

The DE severity increased with the DE wind velocity, but the DE temperature decreased with the DE severity, except for a "moderate dust storm" recorded mostly at the Vík station in S Iceland (Table 2). The parameters show that dust events in S Iceland were more severe than in NE Iceland.

Most of the dust classes in S Iceland occurred in April and May. Severe dust storms were most frequent in March and January at Vík, Hella, Kirkjubæjarklaustur, Hæll, Eyrarbakki and Vatnsskarðshólar stations. The station Vík, located only about $10 \mathrm{~km}$ from the Mýrdalssandur dust source, reported a mean DE visibility of $2 \mathrm{~km}$ indicating very severe dust events. The following stations had the lowest mean DE visibility: Raufarhöfn (NE, $15 \mathrm{~km})$, Höfn $(18.3 \mathrm{~km})$, Kirkjubæjarklaustur $(20.1 \mathrm{~km})$, Stórhöfði $(20.4 \mathrm{~km})$, and Hella $(21.1 \mathrm{~km})$. The highest mean DE wind velocity was measured at the most windy station: Stórhöfði $\left(22.6 \mathrm{~m} \mathrm{~s}^{-1}\right)$; while the lowest mean DE winds were at the station Pingvellir. Pingvellir also recorded the highest mean DE temperature $\left(8.5^{\circ} \mathrm{C}\right)$ in $\mathrm{S}$ Iceland. The lowest $\mathrm{DE}$ temperatures were in Höfn $\left(-2.3{ }^{\circ} \mathrm{C}\right)$ located downwind of the Vatnajökull glacier.

About $18 \%$ of dust days in S Iceland were observed at more than one station at a time (two stations: $12.5 \%$; three stations: $3.4 \%$; four or more stations: $1.5 \%$ ). Dust coobservations were mostly in Kirkjubæjarklaustur and Höfn, Kirkjubæjarklaustur and Vatnsskarðshólar, and Kirkjubæjarklaustur with Hella. The Reykjavík station observed dust together with Hella or Pingvellir.

\subsection{Relationship between $\mathbf{P M}_{10}$ concentrations and visibility}

Hourly $\mathrm{PM}_{10}$ concentrations were compared with the corresponding visibility data during dust observations at available stations. Higher correlation between dust concentration and visibility by power function fitting was found at the station Vík $\left(R^{2}=0.73, n=13\right)$ and Vatnsskarðshólar $\left(R^{2}=\right.$ $0.48, n=219$, Figs. 9a-b) than at the stations Reykjavík and Kirkjubæjarklaustur $\left(R^{2}<0.3, n_{\mathrm{REYK}}=204, n_{\mathrm{KIRK}}=51\right)$. A weak relationship between $\mathrm{PM}_{10}$ concentrations and visibility during dust codes $\left(R^{2}<0.3\right)$ was found at the stations Reykjavík and Kirkjubæjarklaustur. Figure 9c shows the visibility of all available dust codes plotted against corresponding $\mathrm{PM}_{10}$ concentrations together at all stations. Power function analysis resulted in moderate correlation $\left(R^{2}=0.37\right.$, $p<0.01)$. Daily dust concentrations from the high-volume filter aerosol sampler at Stórhöfði during 1997-2002 and 2010 were well correlated with the $24 \mathrm{~h}$ minimum visibility $\left(R^{2}=0.71\right.$, Fig. 9d).

\section{Discussion}

An annual mean of 34 dust days recorded in Iceland is comparable to dust studies from the dust-active parts of China (35 dust days $\mathrm{yr}^{-1}$, Qian et al., 2002), Mongolia (40 dust days $\mathrm{yr}^{-1}$, Natsagdorj et al., 2003), and Iran (Jamalizadeh et al., 2008). The synoptic coding protocols can, however, contribute up to a $15 \%$ underestimation of annual dust day number (O'Loingsigh et al., 2010). Moreover, synoptic codes 04-06 showed a good agreement with increased $\mathrm{PM}_{10}$ concentrations (about $80 \%$ of these codes matched elevated $\mathrm{PM}_{10}$ ). Including these codes into the criteria for dust observation, the annual mean dust day frequency would be fourfold higher than applying conventionally used dust codes for crustal deserts. This results in a total of 135 dust days per year on average for Iceland with 101 dust days observed in $\mathrm{S}$ Iceland and 34 dust days in NE Iceland. Such a high frequency shows that active volcanic and glacial deserts, such as Iceland, differ from the crustal deserts; this is due to the permanent input of volcanic materials, frequent re-suspension of these materials, and the climatic effects of glaciers causing strong down-slope winds. A high number of the dust observations presented here reflect previous studies showing high dust deposition rates in Iceland (Arnalds, 2010; Prospero et al., 2012; Thorarinsdottir and Arnalds, 2012; Bullard, 2013; Arnalds et al., 2013; Arnalds et al., 2014) and places the country among the most important dust producing areas of the world. Iceland is likely to be the largest and most active high-latitude cold dust source.

Trends in global dust emissions show high dust frequency during the 1950-1960s, and low frequency during 1980s in the USA, Australia and China as well as in Iceland (Steenburgh et al., 2012; Ekström et al., 2004; Qian et al., 2002). The 2000s were reported as the most active decade in Iran and in NE Iceland (Jamalizadeh et al., 2008). Dust periods retrieved from the ice-cores data during the GISP2 project in Greenland correlate with the NE Iceland dust frequency in the 1950-1990 period (Donarummo et al., 2002). 

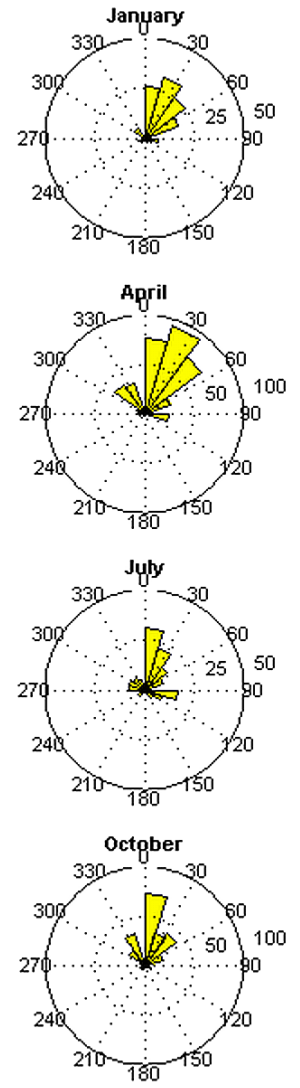
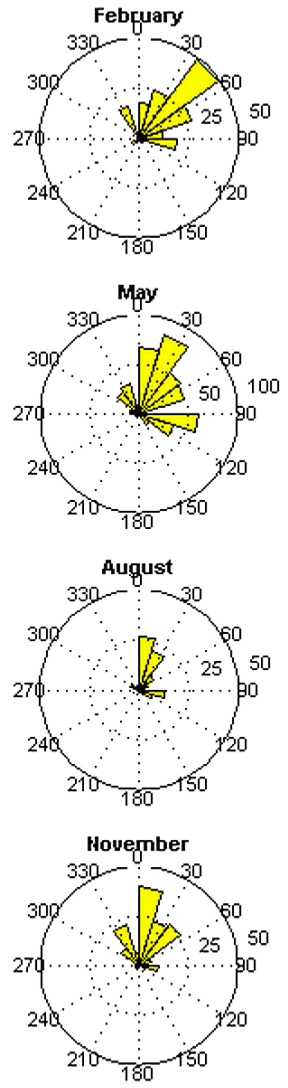
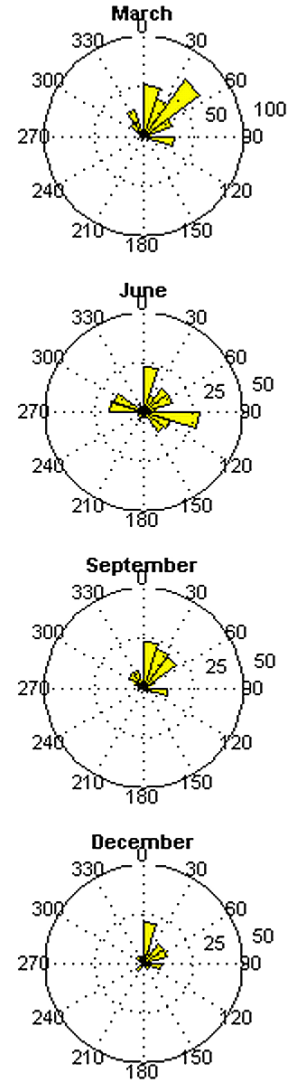

Figure 8. Monthly wind directions during dust events in the southern part of Iceland, 1949-2011. Weather stations that observed mainly wind directions of: 0-18 - Höfn, Eyrarbakki, Kirkjubæjarklaustur, Stórhöfði, Pingvellir; 18-36 - Höfn, Vatnsskarðshólar, Hjarðarland, Reykjavík, Keflavík; 36-54 - Hella, Vatnsskarðshólar, Vík; 54-72 - Hæll, Vatnsskarðshólar; 90-108 - Stórhöfði, Vatnsskarðshólar; 270$306^{\circ}$ - Vatnsskarðshólar; and 306-342 ${ }^{\circ}$ - Höfn. Dashed circles depict the number of dust observations reporting relevant wind directions.

Generally, the period 1950-1965 was warm and dry in Iceland resulting in frequent dust suspension (Hanna et al., 2004). For NE Iceland, the dustiest year was 1955 with 37 dust days, and it coincided with one of the warmest and driest years in NE Iceland (Hanna et al., 2004). For S Iceland, the most productive dust event period was during 1965-1968. It was a period of below-average precipitation, reported at stations Reykjavík, Stykkishólmur and Vestmannaeyjar (Hanna et al., 2004), while 1965 was the driest year in SW Iceland for the past 100 years. The 20th century warm period in Iceland (1920s-1965) ended very abruptly in 1965 with about a $1^{\circ} \mathrm{C}$ drop in mean annual temperature (Hanna et al., 2004). The most exceptional year was, however, the year 1966 with 40 dust days reported in S Iceland. Not only was October 1966 reported as the driest October in Icelandic history, but also February 1966 was the driest February ever reported in Reykjavík. Together with extremely strong maximum winds of more than $40 \mathrm{~m} \mathrm{~s}^{-1}$, the meteorological conditions in February 1966 caused at least 11 days of extremely severe dust storms. Local newspapers reported that several large roofs were removed from houses, ships tore away from the harbours, and planes were turned around (Morgunblaðið, 1966).
The 1970s were cold with high precipitation, but strong winds were often observed in S Iceland bringing the dust into suspension. The 1980s and 1990s were cold and with high precipitation in S Iceland while the 1990s were warm in the NE (Hanna et al., 2004). A high frequency of dust events in NE Iceland during the 2000s was associated with dry and warm Junes. A high number of dust days in S Iceland in 2010 was often due to the resuspension of volcanic ash from the Eyjafjallajökull eruption during very frequent northerly winds (Petersen et al., 2012). The annual differences in dust event frequency do not correspond to trends of the global climate drivers such as the North Atlantic Oscillation (NAO), the Arctic Oscillation or prevailing ocean currents (Dagsson-Waldhauserova et al., 2013). The main driver is likely an orthogonal pattern to NAO, with the dipole of Sea Level Pressure oscillation oriented east-west (DagssonWaldhauserova et al., 2013).

The position of the Icelandic Low determines whether dust plumes travel in a northeasterly or southerly direction. Strong winds in Iceland are almost always associated with extratropical cyclones with strong precipitating systems (fronts). Under such circumstances, there is, in general, only dry weather 

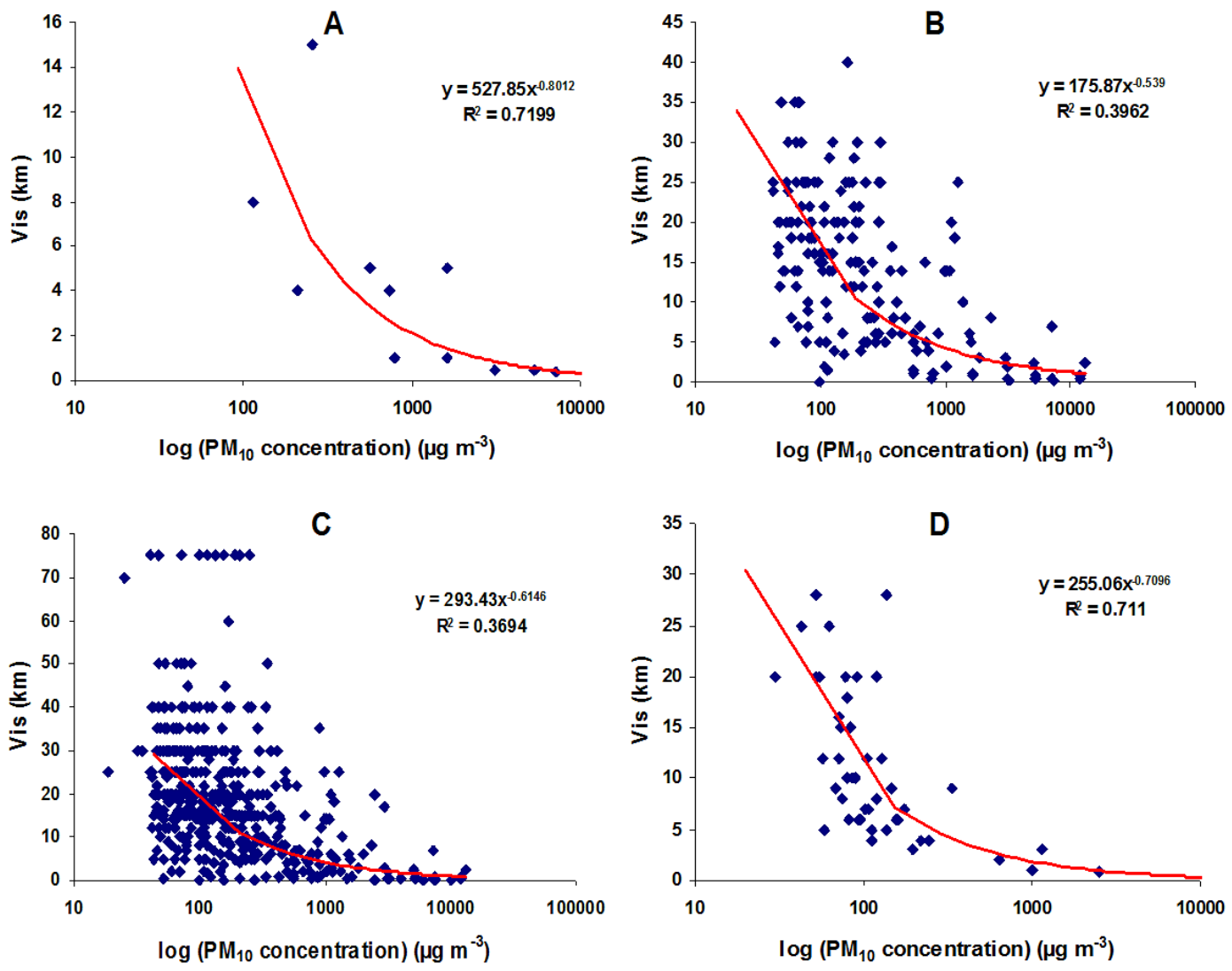

Figure 9. Hourly $\mathrm{PM}_{10}$ concentrations with corresponding visibility (Vis) at stations: (a) Vík, (b) Vatnsskarðshólar, and (c) all stations (Reykjavík, Vík, Vatnsskarðshólar, and Kirkjubæjarklaustur). (d) represents daily $\mathrm{PM}_{10}$ concentrations from the high-volume filter aerosol sampler with corresponding minimum $24 \mathrm{~h}$ visibility at Stórhöfði.

on the downstream side of the central highlands of Iceland, and this is where the dust is suspended. Higher frequency and severity of DE (low visibility and high wind speeds) in $\mathrm{S}$ Iceland than in NE Iceland is likely due to the close proximity of the $\mathrm{S}$ stations to the dust sources, a higher number of major dust sources, as well as a higher number of stations in the south (Fig. 1, Table 2). The Grímsstaðir station (NE) is $>100 \mathrm{~km}$ from the Dyngjusandur source, while the southerly stations are in the range of tens of $\mathrm{km}$ from the sources. Dust deposition rates and DE severity decrease exponentially with distance from the source (Arnalds et al., 2014). This may lead to underestimation of dust events in S Iceland because the stations, located close to the sources, are not able to fully capture the developed dust plume, but only its initiation part, extending several $\mathrm{km}$ in width. The dustiest weather station, Grímsstaðir, is located at a great distance downwind of the most active glacial plain in Iceland, Dyngjusandur, $\mathrm{N}$ of the Vatnajökull glacier, and it captures a high number of dust events. On the other hand, many dust events are not detected, as dust is often blown directly towards the sea from the sources close to the southern coastline, i.e Mýrdalssandur and Skeiðarársandur. However, the most active stations are equally distributed around the areas with very high dust deposition (Arnalds, 2010) from the central NE, SE, S to SW Iceland. The land reclamation activities from the 1950s and 1970s (Crofts, 2011) resulted in decreased dust activity at Hella and Höfn stations (Fig. 2).

The local dust sources in S Iceland are also affected by milder oceanic climate during the winter, while the NE highland dust sources are covered by snow for much of the winter. The DE temperatures were higher in NE Iceland than S Iceland as the events occurred during summer-autumn, and warm geostrophic southerly winds cause the dust events in $\mathrm{NE}$ Iceland. Table 2 shows low DE temperatures in S Iceland, which point to frequent winter-spring dust occurrence and cold strong northerly winds causing dust events in S Iceland. The mean wind speeds are variable each month in $S$ and $\mathrm{NE}$ Iceland. In S Iceland, the highest wind speeds were related to the winter months and April, while in NE Iceland, the windiest months were May-June and September. All these months of high winds correlate with high dust frequency. The northerly winds, which caused dust events in S Iceland, were stronger than the winds in NE Iceland, affecting the results in Table 2.

The visibility during dust observations reflects the severity of the dust events. There is an increasing trend in DE visibil- 
ity through the decades with the maxima in NE as well as $\mathrm{S}$ Iceland in the 2000s (Fig. 2). However, most of the severe dust storms with visibility $<500 \mathrm{~m}$ occurred in S Iceland in the 2000s. These severe dust storms were related to frequent re-suspension of volcanic ashes at the station Vík, located downwind of the Eyjafjallajökull volcano, in 2010. The increase in dust frequency in the 2000s was coincident with a dust visibility increase. The 2000 s were a warmer decade in Iceland compared to the previous decades, 1970s-1990s. This may indicate less availability of fine materials susceptible to dust production determined by changes in flow rates at major glacial rivers in the 2000 s, but the reason remains unclear.

The seasonal distribution of dust events in Iceland shows that the high dust period is from March to October. The NE dust events are typically warm, occurring during summer and autumn (May-September) while the $\mathrm{S}$ dust events are mainly cold, occurring during winter and spring (March-May). This is related to the sea level pressure pattern which controls the warm southerly winds in NE Iceland and the cold northerly winds in S Iceland (Bjornsson and Jonsson, 2003). The S dust events were, however, more equally distributed throughout the year. The winter season is related to mild temperatures and high winds in S Iceland. Relatively high mean dust concentrations were measured during winter (JanuaryMarch) at Stórhöfði station (Prospero et al., 2012). Winter cold dust storms were frequently also observed in Mongolia (Natsagdorj et al., 2003). The highest number of dust storms occurred in March-May while the mean March-April temperatures were sub-zero.

The predominant winds during dust events were NE and NNE winds in March and April, when the mean wind speeds were about $15 \mathrm{~m} \mathrm{~s}^{-1}$. The DE winds in May were also frequently $\mathrm{N}$ and $\mathrm{NE}$ winds, but a high proportion of $\mathrm{E}$ and $\mathrm{ESE}$ winds occurred during dust events. In May, the wind speeds were lower than in March and April, but the high dust occurrence was likely caused by the dry conditions. May is the driest and dustiest month in Iceland, while June and September are the driest months only in NE Iceland (Hanna et al., 2004; Dagsson-Waldhauserova et al., 2013). The DE wind speeds in S Iceland decreased further during the summer and autumn, and the summer months typically had high precipitation. This trend was followed by a rapid decrease in dust frequency from June to September in S Iceland (Fig. 4).

There are several processes responsible for dust events in Iceland. The main drivers were strong winds during periods of low precipitation, enhanced by a limited hygroscopicity of the materials and rapid drying of the dark-coloured surfaces. Dust events in NE Iceland occurred mainly during summer, when the highland dust sources were snow-free and under relatively mild temperatures; while in S Iceland, the dust events occurred also during very low and sub-zero temperatures. Nevertheless, dust events can also be observed during high precipitation seasons $<4 \mathrm{~h}$ after rain (DagssonWaldhauserova et al., 2014). For instance, even the high- est precipitation year (1972) had a relatively high dust frequency. The majority of dust events reported in this longterm study were observed during strong winds.

Visibility during dust observations is an important indicator of dust event severity. To estimate the empirical relationship between visibility and dust concentration in Iceland, we compared available $\mathrm{PM}_{10}$ concentrations with visibility based on methods in Wang et al. (2008). We found moderate correlation $\left(R^{2}=0.37, p<0.01\right)$ between dust concentrations and visibility which was likely due to several factors: (i) visibility was not measured but observed visually and only the prevailing visibility $\left(\varphi>180^{\circ}\right)$ recorded; (ii) generally low number of measurements, (iii) the stations were located in different distance of each other, (iv) time resolution between the dust and weather measurements, and (v) station Reykjavík with majority of the measurements was influenced by anthropogenic aerosols. More observations are therefore needed to obtain large data set for further quantitative analyses including estimation of extinction coefficients from the $\mathrm{PM}_{10}$ mass concentrations based on the mass scattering efficiencies to be investigated in detail (Hand and Malm, 2007).

The relationship between available $\mathrm{PM}_{10}$ concentrations and visibility during dust events showed lower $\mathrm{PM}_{10}$ concentrations for low visibilities $(<1 \mathrm{~km})$ than expected (see calculations in Dagsson-Waldhauserova et al., 2013). Icelandic data, similar to Australian data from the so-called "Red Dawn" dust storm (Leys et al., 2011), consist of a relatively high number of PM measurements of low dust visibilities $(<500 \mathrm{~m})$. In contrast, PM measurements of such low dust visibilities are rare in the study of China (Wang et al., 2008). The power function calculated for the PM concentration and visibility in the study of China resulted in extremely high concentrations for low dust visibilities in steppe areas. The calculated PM concentrations from visibility in NE Iceland were partly estimated from these steppe areas and therefore overestimated (Dagsson-Waldhauserova et al., 2013). The first results here, based on the fit functions between the visibility and $\mathrm{PM}_{10}$ concentrations from $\mathrm{S}$ Iceland, were comparable to the PM concentrations during dust event conditions on Australian sand plains, sandy areas of the Taklamakan Desert and marginal parts of the Gobi Desert (Wang et al., 2008; Leys et al. 2011).

This study on long-term dust frequency showed high dust day frequency in the volcanic and glacial deserts of Iceland. Several dust plumes, captured by the Moderate Resolution Imaging Spectroradiometer (MODIS) onboard the Terra satellite, exceeded $1000 \mathrm{~km}$ travelling towards Europe, North America and the Arctic. Further, it was calculated that dust is deposited over $370000 \mathrm{~km}^{2}$ of the oceanic area around Iceland, carrying 6-14 million tons of dust annually (Arnalds et al., 2014). The dust contains high amounts of bioavailable iron. The data presented here showed that the majority of the dust is transported in early spring in southern parts of Iceland. Oceanic biochemical cycles and productivity might therefore be affected by local aeolian processes. We also em- 
phasise here that high dust event frequency and long-range transport of Icelandic dust may affect the environment and climate on a macro scale. Icelandic dust aerosol should be included in climate projections, and in studies of European and Arctic air pollution.

\section{Conclusions}

This study of long-term dust observations in Iceland showed that dust day frequency in Iceland can be comparable to the major desert areas in the world. It was found that dust events often occurred during winter and at sub-zero temperatures. Observed dust events were more severe in S Iceland than in NE Iceland, most likely because of the closer proximity of the southerly weather stations to major dust sources. The highest frequency of dust events was during the 1960s in S Iceland while most of the dust events in NE Iceland occurred during the 2000s. The highest number of severe dust storms (visibility $<500 \mathrm{~m}$ ) was observed in S Iceland during the 2000s. Monitoring dust frequency in active volcanic and glacial deserts requires the inclusion synoptic codes for "visibility reduced by volcanic ashes" and "dust haze" into the criteria for dust observation. A moderate correlation was found between available $\mathrm{PM}_{10}$ concentrations and visibility during the dust observations in Iceland. More synchronised dust and weather measurements are therefore needed. Iceland can be considered as the largest and most active desert and dust source at the boundary of the Arctic and subarctic region.

Acknowledgements. The work was supported by the Eimskip Fund of The University of Iceland and by the Nordic Centre of Excellence for Cryosphere-Atmosphere Interactions in a Changing Arctic Climate (CRAICC). We would like to thank Joseph Prospero from the University of Miami, USA, and Thorsteinn Johannsson from the Environment Agency of Iceland for providing the PM data for the dust measurements.

Edited by: A. Stohl

\section{References}

Arnalds, O.: Dust sources and deposition of aeolian materials in Iceland, Icel. Agr. Sci., 23, 3-21, 2010.

Arnalds, O., Thorarinsdottir, E. F., Thorsson, J., DagssonWaldhauserova, P., and Agustsdottir, A. M.: An extreme wind erosion event of the fresh Eyjafjallajökull volcanic ash, Nature Sci. Rep., 3, 1257, doi:10.1038/srep01257, 2013.

Arnalds, O., Olafsson, H., and Dagsson-Waldhauserova, P.: Quantification of iron-rich volcanogenic dust emissions and deposition over ocean from Icelandic dust sources, Biogeosciences Discuss., 11, 5941-5967, doi:10.5194/bgd-11-5941-2014, 2014.
Bjornsson, H. and Jonsson, T.: Climate and climatic variability at Lake Mývatn, Aquat. Ecol., 38, 129-144, 2003.

Bullard, J. E.: Contemporary glacigenic inputs to the dust cycle, Earth Surf. Proc. Land., 38, 71-89, 2013.

Crofts, R. (Ed.): Healing the Land, Soil Conservation Service of Iceland, Reykjavik, Iceland, 2011.

Crusius, J., Schroth, A. W., Gasso, S., Moy, C. M., Levy, R. C., and Gatica, M.: Glacial flour dust storms in the Gulf of Alaska: hydrologic and meteorological controls and their importance as a source of bioavailable iron, Geophys. Res. Lett., 38, L06602, doi:10.1029/2010GL046573, 2011.

Dagsson-Waldhauserova, P., Arnalds, O., and Olafsson, H.: Longterm frequency and characteristics of dust storm events in Northeast Iceland (1949-2011), Atmos. Environ., 77, 117-127, 2013.

Dagsson-Waldhauserova, P., Arnalds, O., Olafsson, H., Skrabalova, L., Sigurdardottir, G. M., Branis, M., Hladil, J., Skala, R., Navratil, T., Chadimova, L., von Lowis of Menar, S., Thorsteinsson, T., Carlsen, H. K., and Jonsdottir, I.: Physical properties of suspended dust during moist and low-wind conditions in Iceland, Icel. Agr. Sci., 27, 2014.

Dörnbrack, A., Stachlewska, I. S., Ritter, C., and Neuber, R.: Aerosol distribution around Svalbard during intense easterly winds, Atmos. Chem. Phys., 10, 1473-1490, doi:10.5194/acp10-1473-2010, 2010.

Donarummo, J. J., Ram, M., and Stolz, M. R.: Sun/dust correlations and volcanic interference, Geophys. Res. Lett., 29, 1361 , doi:10.1029/2002gl014858, 2002.

Ekström, M., McTainsh, G. H., and Chappell, A.: Australian dust storms: temporal trends and relationships with synoptic pressure distributions (1960-99), Int. J. Climatol., 24, 1581-1599, 2004.

Eldridge, F. R. (Ed.): Wind Machines, edited by: Van Nostrand, R., New York, USA, 1980.

Engelstaedter, S., Kohfeld, K. E., Tegen, I., and Harrison, S. P.: Controls of dust emissions by vegetation and topographic depressions: an evaluation using dust storm frequency data, Geophys. Res. Lett., 30, 1294, doi:10.1029/2002GL016471, 2003.

Fields, J. P., Belnap, J., Breshears, D. D., Neff, J. C., Okin, G. S., Whicker, J. J., Painter, T. H., Ravi, S., Reheis, M. C., and Reynolds, R. L.: The ecology of dust, Front. Ecol. Environ., 8, 423-430, 2010.

Ganopolski, A., Calov, R., and Claussen, M.: Simulation of the last glacial cycle with a coupled climate ice-sheet model of intermediate complexity, Clim. Past, 6, 229-244, doi:10.5194/cp-6-2292010, 2010.

Hand, J. L. and Malm, W. C.: Review of aerosol mass scattering efficiencies from ground-based measurements since 1990, J. Geophys. Res., 112, D16203, doi:10.1029/2007JD008484, 2007.

Hanna, E., Jonsson, T., and Box, J. E.: An analysis of Icelandic climate since the nineteenth century, Int. J. Climatol., 24, 1193 1210, 2004.

IMO: Reglur um veðurskeyti og veðurathuganir, Weather Observer Handbook, The Icelandic Meteorological Office, Reykjavik, Iceland, 85 pp., 1981.

Jamalizadeh, M. R., Moghaddamnia, A., Piri, J., Arbabi, V., Homayounifar, M., and Shahryari, A.: Dust Storm Prediction Using ANNs Technique (A Case Study: Zabol City), Proc. World Aca. Sci. Eng. Tech., 33, 529-537, 2008.

Leys, J. F., Heidenreich, S. K., Strong, C. L., McTainsh, G. H., and Quigley, S.: $\mathrm{PM}_{10}$ concentrations and mass transport during 
“Red Dawn” Sydney September 2009, Aeolian Res., 3, 327-342, 2011.

Morgunblaðið: Pök fjúka af húsum, skip slitna upp, Roofs blow off houses, boats tore away, 1, available at: http://timarit.is/view_page_init.jsp?issId=113054\&pageId= 1372641\&lang=is\&q=1966 (last access: 4 April 2014), 1966.

N'Tchayi Mbourou, G., Berrand, J. J., and Nicholson, S. E.: The diurnal and seasonal cycles of wind-borne dust over Africa north of the Equator, J. Appl. Meteorol., 36, 868-82, 1997.

Natsagdorj, L., Jugder, D., and Chung, Y. S.: Analysis of dust storms observed in Mongolia during 1937-1999, Atmos. Environ., 37, 1401-1411, 1978, 2003.

Nickling, W. G.: Eolian sediment transport during dust storms: Slims River Valley, Yukon Territory, Can. J. Earth Sci., 15, 1069 1084, 1978.

O’Loingsigh, T., Mc Tainsh, G., Tapper, N., and Shinkfield, P.: Lost in code: a critical analysis of using meteorological data for wind erosion monitoring, Aeolian Res., 2, 49-57, 2010.

Petersen, G. N., Björnsson, H., and Arason, T.: The impact of the atmosphere on the Eyjafjallajökull 2010 eruption plume, Geophys. Res. Lett., 117, D00U07, doi:10.1029/2011JD016762, 2012.
Prospero, J. M., Bullard, J. E., and Hodgkins, R.: High-latitude dust over the North Atlantic: Inputs from Icelandic proglacial dust storms, Science, 335, 1078, doi:10.1126/science.1217447, 2012.

Qian, W. H., Quan, L., and Shi, S.: Variations of the dust storm in China and its climatic control, J. Climate, 15, 1216-1229, 2002.

Steenburgh, W. J., Massey, J. D., and Painter, T. H.: Episodic dust events of Utah's Wasatch front and adjoining region, J. Clim. Appl. Meteorol., 51, 1654-1669, 2012.

Thorarinsdottir, E. F. and Arnalds, O.: Wind erosion of volcanic materials in the Hekla area, South Iceland, Aeol. Res., 4, 39-50, 2012.

Wang, Y. Q., Zhang, X. Y., Gong, S. L., Zhou, C. H., Hu, X. Q., Liu, H. L., Niu, T., and Yang, Y. Q.: Surface observation of sand and dust storm in East Asia and its application in CUACE/Dust, Atmos. Chem. Phys., 8, 545-553, doi:10.5194/acp-8-545-2008, 2008.

WMO: Manual on Codes: International Codes, Vol. I.1 (Part A Alphanumeric Codes). World Meteorological Organization Report WMO-No. 306, available at: http://www.wmo.int/pages/ prog/www/WMOCodes.html, (last access: 6 Nov 2014), 2009. 